Relations industrielles

Industrial Relations

\title{
Gray, Lois S., and Ronald L. Seeber, eds, Under the Stars: Essays on Labor Relations in Arts and Entertainment
}

\section{Grant Michelson}

Volume 51, numéro 4, 1996

URI : https://id.erudit.org/iderudit/051140ar

DOI : https://doi.org/10.7202/051140ar

Aller au sommaire du numéro

Éditeur(s)

Département des relations industrielles de l'Université Laval

ISSN

0034-379X (imprimé)

1703-8138 (numérique)

Découvrir la revue

Citer ce compte rendu

Michelson, G. (1996). Compte rendu de [Gray, Lois S., and Ronald L. Seeber, eds, Under the Stars: Essays on Labor Relations in Arts and Entertainment]. Relations industrielles / Industrial Relations, 51(4), 847-849.

https://doi.org/10.7202/051140ar

Tous droits réservés @ Département des relations industrielles de l'Université Laval, 1996
Ce document est protégé par la loi sur le droit d'auteur. L’utilisation des services d'Érudit (y compris la reproduction) est assujettie à sa politique d'utilisation que vous pouvez consulter en ligne.

https://apropos.erudit.org/fr/usagers/politique-dutilisation/ 
of blurring the labour-capital distinction. For example, will union members who invest in labour investment funds "support labour's political agenda (such as higher corporate taxes) if these policies have an adverse impact on the financial return to their fund?" For worker buyouts, will worker-owners "accept lower pay settlements than are necessary... [or] refuse to support industry-wide strikes"? Will worker-owners even continue to see the union as necessary? Although there are no clear answers to the first two questions, Quarter cites research indicating that, by and large, union members do not abandon the union after employee ownership.

Overall, this is a very thorough and thoughtful book. However, one notable omission is that it gives virtually no attention to partial employee ownership, after identifying it as one of three ways in which labour is "crossing the line" with capital. Perhaps this is because these plans are not as dramatic as worker buyouts, but the fact remains that employee stock plans will affect a great many more unionized employees than will worker buyouts. Another shortcoming, albeit a minor one, is an impression conveyed by the author that the labour movement is undergoing a massive shift in attitudes toward the traditional separation between labour and capital. In fact, with the exception of one or two unions, such as the CSN or the United Steelworkers, most unions are quite unenthusiastic about the idea of worker ownership, although they may not be as hostile as in the past. Even in regard to labour investment funds, the two largest federations, the Canadian Labour Congress and the Ontario Federation of Labour have not moved. There is still a great deal of traditional thinking in Canadian labour organizations. But however you look at it, Jack Quarter's book is a very useful contribution to our knowledge about a phenomenon that does seem destined to become increasingly common in the Canadian landscape.

RICHARD J. LONG University of Saskatchewan

\section{Under the Stars: Essays on Labor Relations in Arts and Entertainment} edited by Lois S. GRAY and Ronald L. SEEBER, Ithaca, N.Y., ILR Press, 1996, 207p., ISBN 0-87546-350-9 (hbk) and ISBN 0-87546-349-5 (pbk).

Is Hollywood ubiquitous? The dominance and pervasiveness of the U.S. motion picture and broadcasting industries would suggest that it is. Far-reaching and rapid technological change, increasingly concentrated and vertically integrated ownership structures and constantly evolving product markets have contributed to the shift towards globalization of popular entertainment since the 1970s. Without question, these changes have impacted dramatically on those who work within the arts and entertainment industries. It is perhaps surprising then that relatively little scholarly research has been undertaken which examines the industrial relations consequences of salient environmental developments, a point buttressed by the extensive use of industry sources to construct the current book's bibliography. The prior invisibility of the arts and entertainment sectors to industrial relations researchers itself raises an interesting question given that entertainment in its many forms is a highly visible and economically significant activity. Could an explanation of the dearth of research rest in part on a (false) premise that entertainment does not involve employment relationships? Whatever the reasons, Under the Stars is a welcome addition to the small but growing literature on industrial relations in arts and entertainment.

The editors set technological developments up as the primary explanatory factor in shaping patterns of industrial 
relations. In this context, while the volume purports to be a study of live performing arts (opera, ballet, theater and dance), recordings, motion pictures and broadcasting (television and radio), the emphasis is really placed on the latter two areas principally because motion pictures and broadcasting have been most heavily effected by technology. What is of most interest here is that the environmental change has impacted differently on different groups of workers depending on their location in the labour process: for those employed below-the-line (technicians) the consequences of new technology have been far more deleterious than for those working above-the-line (talent or performers). Declining memberships have characterized below-the-line unions as jobs have become obsolete because of new equipment, whilst abovethe-line unions have tended to enjoy growth. This distinction is reflected by the book's rather pithy title.

The book is a collection of six chapters written by contributors from the fields of industrial relations, geography and public policy. Edited collections can often prove disappointing due to variations in chapter quality and a lack of organizational logic among chapters. Fortunately, Gray and Seeber largely avoid these potential weaknesses; the quality of material is generally consistent throughout and each chapter follows a rational sequence. The book proceeds from providing a macro perspective of the industries at the outset (Chapter One), through to more specific micro analyses of the consequences of the environmental changes (Chapters Four and Five).

Chapter One by Gray and Seeber charts the industries, the oligopolistic nature of ownership, the main unions and the prevailing bargaining structures. It also introduces the pivotal role played by technology in influencing employment and industrial relations and how the various unions have responded to this. The next chapter written by Les Brown examines in more detail the technological revolu- tion including miniaturization of equipment, satellite cable networks and highdefinition television while Susan Christopherson in Chapter Three elaborates on changes in production and ownership structures. It shows how the ability of some unions to control the supply of industry labour was eroded following such changes which, in turn, blurred union jurisdictions and dismantled craft solidarity.

The plight of craft workers is expanded by John Amman in Chapter Four which illustrates how new technology essentially deskilled many technical jobs. This, in conjunction with a more belligerent approach from employers who were themselves seeking concessions from the unions as a result of intense competition, helped to undermine union bargaining strength. What followed was that the unions were largely unable to protect many of their full-time members' jobs. Freelance and per diem employment is now a reality for many of those remaining craft workers in television. Amman is cautiously optimistic about the future for below-the-line unions given that the industries are still relatively labour intensive. He argues that the strategies of these unions must change and suggests recruitment drives, mergers and representation of freelance workers as possible initiatives.

The penultimate chapter, which focused on talent unions, was regarded as the most engaging and theoretically informative of the essays. Jointly written by Alan Paul and Archie Kleingartner, it provided a fascinating discussion of how above-the-line unions have sought ways of increasing their relevance despite rapid technological change. Unlike the technical unions which had become increasingly marginalized, talent unions have adapted by cementing for themselves an integral role in the administration of the industries complex remuneration structures. In other words, technological change has been accommodated within the performers' compensation system 
(p. 174). The structures of collective bargaining have been responsible for producing transformation in the industry, a point which challenges the thesis of Kochan, Katz and McKersie who contend that actors' top level strategic choices have had the greatest impact in changing U.S. industrial relations.

Chapter Six by Gray and Seeber summarizes the general topics and themes of the volume, extrapolates current trends and challenges and argues that industrial relations in arts and entertainment will continue to remain dynamic in the foreseeable future.

The relative brevity of Under the Stars (207 p.) left this reviewer somewhat unsatisfied. Perhaps the editors could have commissioned some additional material to deal with what appears to be largely unaddressed issues. The first of such recommendations lies in the fact that a central thesis of the book is not watertight. That is, there are some notable inconsistencies in the proposition that above-the-line unions have fared better than below-the-line unions in the process of technological change. One talent union, the American Federation of Musicians, has stagnated while a below-theline union, the National Association of Broadcast Engineers and Technicians, has experienced strong membership growth (p. 34-35). It would be most interesting to understand why a contrary pattern is evident from these cases. Secondly, and not necessarily unrelated to the first suggestion, would be to devote more space to an explicit and in-depth discussion of management strategy and behaviour. This would provide more balance to the volume which is slanted towards unions and, in addition, might allow further teasing out of propositions relevant to the complex interplay between technology, product and labour markets, regulatory structures, management and labour.

While the implications of the book for other rapidly changing industries may be tempered by the idiosyncracies of the entertainment industry (chronic levels of unemployment, extensive reliance on casualized labour, secondary usage of material, copyright matters, and elaborate and delayed forms of remuneration including residual payments), this does not detract from its importance. Under the Stars has provided an up-to-date analysis of industrial relations in motion pictures and broadcasting. It will surely serve to enhance the profile of these industries among the academic community, and to inform the work of others also interested in these sectors, both in North America and elsewhere.

GRANT MICHEISON

The University of Sydney

\section{On Strong Foundations: The BWIU and Industrial Relations in the Australian Construction Industry, 1942-1992}

by Glenn MITCHELL, Toronto, Harcourt, Brace and Co., 1996, 368 p., ISBN 07295-3339-5.

Cette monographie présente l'histoire du Syndicat industriel des travailleurs de la construction (Building Workers' Industrial Union - BWIU), en Australie, de 1942 à 1992. L'ouvrage de Mitchell est intéressant en ce qu'il relate une expérience entièrement différente de la tendance générale observée en Amérique du Nord au chapitre des structures syndicales dans l'industrie de la construction et, partant, à leur approche générale en relations du travail. Certes, en Australie, comme partout ailleurs, les syndicats ne représentent pas un phénomène récent dans l'industrie de la construction, mais l'originalité de l'expérience australienne réside dans l'évolution d'un grand nombre de syndicats de métier 